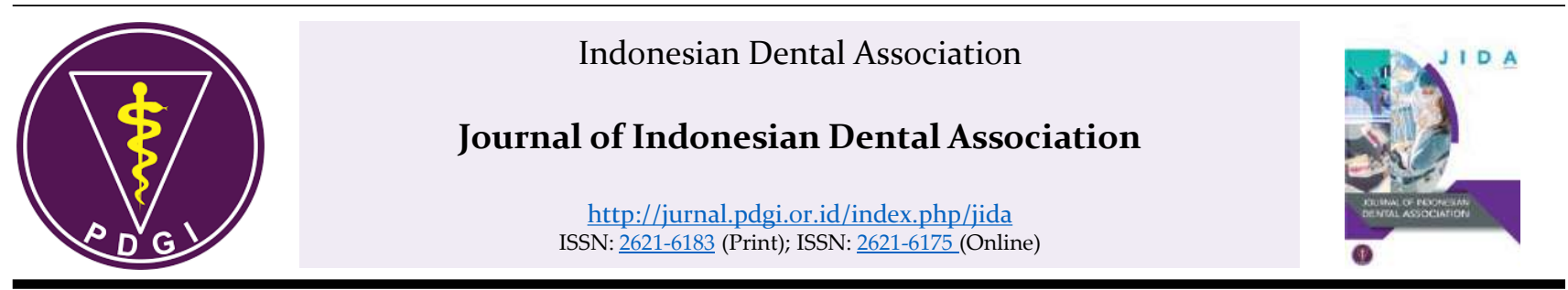

Research Article

\title{
Overview of the Total Bacteria and Number of Streptococcus mutans in the Saliva of Children with high caries activity
}

\author{
Natasya Putri Hardini Yanis ${ }^{1}$, Tri Putriany Agustin ${ }^{2 \S}$ \\ ${ }^{1}$ Undergraduate Student, Faculty of Dentistry, Trisakti University, Indonesia \\ ${ }^{2}$ Department of Pediatric, Faculty of Dentistry, Trisakti University, Indonesia
}

Received date: September 17, 2019. Accepted date: December 22, 2019. Published date: February 20, 2020.

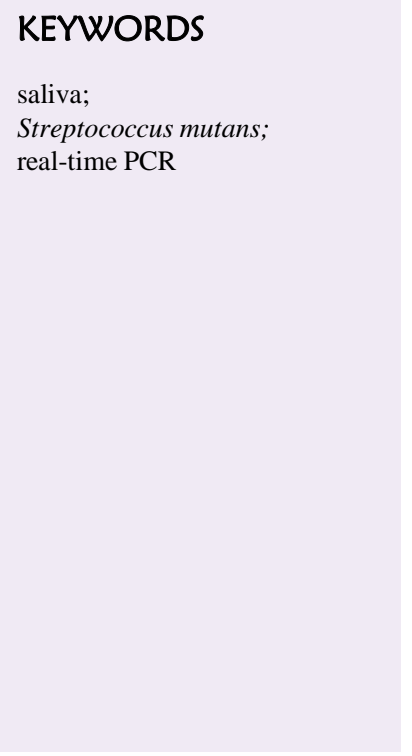

\begin{abstract}
Introduction: Microorganisms play a crucial role in the early stage of caries. Streptococcus mutans produces lactic acid, which enhances the risk of caries. Polymerase chain reaction (PCR) is a molecular biology technique used in the amplification and replication of DNA. PCR exhibits high specificity and a rapid detection time, as well as differentiation between microorganisms. Based on a previous study, there is a significant correlation between $S$. mutans in saliva and the prevalence of caries. Objectives: To provide an overview of the total bacteria and number of $S$. mutans in the saliva of children aged between 5 and 10 years at the Department of Pediatric, Faculty of Dentistry, Trisakti University, Jakarta, Indonesia. Methods: Saliva sample from children $(n=28$, aged 5-10 years old) was collected from healthy children. 2-3 mL of a saliva samples were collected and cultured by using TYS media for total bacterial count. The number of $S$. mutans in the saliva of these children was counted by real-time PCR methods by using a fluorescence chemical compound green SYBR using $16 \mathrm{~S}$ rRNA gene specific primers for $S$. mutans. Results: The average number of total bacterial colony count in saliva was $9.965 \pm 2.078 \log 10 \mathrm{CFU} / \mathrm{mL}$, and the average number of $S$. mutans in the saliva of children was $8.303 \pm 2.351 \log 10 \mathrm{CFU} / \mathrm{mL}$. Conclusion: The number of $S$. mutans in the saliva of children in Department of Pediatric, Faculty of Dentistry, Trisakti University was categorized is in the high-risk.
\end{abstract}

${ }^{\S}$ Corresponding Author

E-mail address: titinazhar@yahoo.co.id (Agustin TP) 


\section{INTRODUCTION}

Dental caries continues to be the main problem in dental health. Caries is prevalent in the permanent teeth of 2.43 billion people worldwide, accounting for $36 \%$ of the total population. Caries is observed in the primary teeth of 620 million children, which is equivalent to $9 \%$ of the total population. ${ }^{1}$ In Indonesia, the percentage of the population who have dental and oral health problems based on Indonesian Basic Health Research (RISKESDAS) in 2013 and 2018 increase from $25.9 \%$ to $57.6 \%$ with the difference of $31.7 \%$, indicating that caries remains a major problem for the Indonesian population and continues to increase every year. ${ }^{2}$

Dental caries is a disease of the hard tissue of the tooth, involving some factors and related to one another, caused by the interaction between tooth, saliva (host), microorganisms, substrate and time. ${ }^{3}$ A study conducted at the Department of Pediatric, Airlangga University in 2008 revealed that there is a significant difference between the number of Streptococcus mutans and Lactobacillus sp. in children with caries. In children with caries, they found that the number of $S$. mutans is greater than that of the Lactobacillus sp. ${ }^{4}$ This result indicated that $S$. mutans is the main microorganism in the early developmental stage of caries. ${ }^{5,6}$

Streptococcus mutans exhibits some characteristics, including the ability to form colonies and attachment to the tooth surface; ability to synthesize sucrose for conversion to acid; and ability to decrease the oral cavity $\mathrm{pH}$ level. $^{3} S$. mutans produces lactic acid as a side product from the metabolism of carbohydrates, which dissolves the tooth mineral and causes caries. ${ }^{6}$ S. mutans is thought to play a role in the early developmental stage of caries, and Lactobacillus sp. is found in active caries. A study revealed that both bacteria are found in children with caries and caries-free children, but the number of Lactobacillus sp. is less than that of $S$. mutans due to its multiplication ability. ${ }^{7}$ Determination of the caries activity is crucial to select an appropriate treatment plan. Caries activity can be defined as the pace of tooth decay, marked with new caries and the development of previous caries lesions within a certain period. ${ }^{8}$ Based on visual examination, it is difficult to predict caries in children. Several microbiology examinations have been introduced to help in the determination of the caries activity. The microorganism test can be performed by taking a saliva or plaque sample. Saliva can be used as the main component in several caries activity tests and helps in the categorization of patients into a high, medium, or low caries activity group. ${ }^{9}$

The research that was conducted at the Pediatric Dentistry Clinic at Faculty of Dentistry Trisakti
University Dental Hospital in 2013 showed that of the 101 children aged 6-12 year old examined all of children had caries at first permanent molars, that indicate the prevalence of caries of children coming to the Faculty of Dentistry Trisakti University Dental Hospital is still high. Most of patients who come to our hospital were middle to low economic status. The impact of socio-economic on caries activity on children has never been done in the Pediatric Dentistry Clinic at Faculty of Dentistry Trisakti University Dental Hospital. Researchers are interested in conducting research on the overview of the total number of bacteria and the number of $S$. mutans in saliva of pediatric patients using PCR methods.

One of the technologies in molecular biology involves the identification of bacteria in the oral cavity by polymerase chain reaction (PCR). PCR permits the amplification and replication from one DNA and produces two to four duplicates until a million duplicates of DNA are attained. PCR is more sensitive than the culture method for the detection of bacterial species. PCR is a rapid, simple method, and it can detect low numbers of bacteria. ${ }^{10}$

\section{MATERIALS AND METHODS}

This study is a descriptive observational study with a cross-sectional design conducted at the Oral and Dental Hospital, Faculty of Dentistry, Trisakti University to provide an overview of the total bacteria and number of S. mutans in the saliva of children. The sample included saliva from 28 healthy children aged between 5 and 10 years at the Pediatric Dentistry Clinic at Faculty of Dentistry, Trisakti University. Saliva collected from these children for 2-3 mL was spitted into a tube and carried to the Microbiology Research and Education Center (MiCORE) laboratory, Faculty of Dentistry, Trisakti University, for counting the total number of bacteria in the TYS media and number of $S$. mutans by real-time PCR with extraction, detection, and quantification of the DNA target $S$. mutans. The DNA quantification result was obtained by real-time PCR by using a fluorescence chemical compound green SYBR using 16s rRNA forward and reverse primers for $S$. mutans specific gene (Table 1). Moreover, the result was converted by using a standard curve, and the total number of bacteria was expressed in colony forming unit (CFU). Ethical approval number from Ethics Committee Faculty of Dentistry, Trisakti University in this study is 238/S1/KEPK/FKG/11/2018.

\section{Saliva Sampling}

The samples were obtained from patients that had not consumed food and liquid and had brushed their teeth $1 \mathrm{~h}$ before sampling. The children were instructed to sit 
in an upright position, with their head slightly leaning to the front and their mouth opened, and saliva was allowed to drool into a container till a minimum of $2-3 \mathrm{~mL}$ of saliva was collected. The saliva was taken to the microbiology laboratory for bacterial culture using TYS media within $2 \mathrm{~h}$.

Table 1. Primers used in this study ${ }^{10,11}$

\begin{tabular}{ll}
\hline \multicolumn{1}{c}{ Primers } & \multicolumn{1}{c}{ Sequence (5'-3') } \\
\hline S. mutans serotype & GCC TAC AGC TCA GAG \\
c Forward & ATG CTA TTC T \\
S. mutans serotype & GCC ATA CAC CAC TCA \\
c Reverse & TGA ATT GA \\
\hline
\end{tabular}

\section{Sample Culture}

The saliva sample was homogenized (vortex) for 5 min and diluted until achieving a bacterial number of $10^{2}$. The TYS media was added to the saliva, and $20 \mu \mathrm{L}$ of saliva was removed and poured into a petri dish. The petri dish was stored in an incubator at $37^{\circ} \mathrm{C}$ for $24 \mathrm{~h}$. After $24 \mathrm{~h}, S$. mutans was manually counted. The petri dish was divided into four quadrants, and each quadrant was counted. Counting was performed twice to avoid any mistakes.

\section{Extraction of Saliva DNA Using The Heat Shock Method}

The saliva sample was dissolved and centrifugation at $\mathrm{f} 4.500 \mathrm{~g}$ for $15 \mathrm{~min}$. The supernatant was removed, and the pellet containing bacteria was obtained. Then, 1 $\mathrm{mL}$ of PBS was inserted into a macro-centrifuge tube with a pellet for washing and re-centrifuged at $10.000 \mathrm{~g}$ for $10 \mathrm{~min}$. The supernatant was removed, and the supernatant was added to $100 \mu \mathrm{L}$ of $\mathrm{dd}_{2} \mathrm{O}$ and transferred to a $1.5 \mathrm{~mL}$ microcentrifuge tube. The tube was subsequently incubated in a dry heatblock for $20 \mathrm{~min}$ at $100^{\circ} \mathrm{C}$. Moreover, the $1.5 \mathrm{~mL}$ micro-centrifuge tube was transferred into ice for $10 \mathrm{~min}$. The supernatant was obtained and transferred into a new $1,5 \mathrm{~mL}$ microcentrifuge tube.

\section{Real-time PCR}

DNA-extracted bacteria were diluted with Nuclease Free Water (NFW) before adding into the PCR mix. Eight $\mu \mathrm{L}$ was added into each PCR tube. Two $\mu \mathrm{L}$ of the DNA sample with the same concentration was added into the PCR tube. Dilution bacterial standard (each bacteria) was added into the PCR tube. The PCR tube was filled with the PCR mix and sample, covered, and subjected to centrifugation at $1500 \mathrm{~g}$ or $1 \mathrm{~min}$. Subsequently, the PCR tube was inserted into the PCR machine, and the temperature and plate design were programmed with a computer connected to the PCR machine. Third, the PCR process took $\sim 2 \mathrm{~h}$, and the PCR result was saved and analyzed.

\section{RESULTS}

Present study result showed from 28 subjects, subject 15 exhibited the highest total bacterial colony count of $10.85 \log 10 \mathrm{CFU} / \mathrm{mL}$ (Fig. 1). Table 2 shows the average of total bacterial colony count and number of $S$. mutans in saliva. In 28 subjects, the average number of total bacterial colony count in saliva was $9.965 \log 10$ $\mathrm{CFU} / \mathrm{mL}$, and the average number of $S$. mutans in the saliva of children was $8.303 \log 10 \mathrm{CFU} / \mathrm{mL}$. Subjects 16 and 18 exhibited the highest numbers of $S$. mutans of $15.882 \log \mathrm{CFU} / \mathrm{mL}$ and $15.961 \log 10 \mathrm{CFU} / \mathrm{mL}$, respectively (Fig. 2).

Table 2. Total number of bacteria and $\mathrm{S}$. mutans in saliva

\begin{tabular}{cc}
\hline & $\begin{array}{c}\text { Mean } \pm \text { St. Dev } \\
(\log 10 \text { CFU/mL) }\end{array}$ \\
\hline Total plate count & $9.965 \pm 2.078$ \\
Streptococcus mutans & $8.032 \pm 2.351$ \\
\hline
\end{tabular}

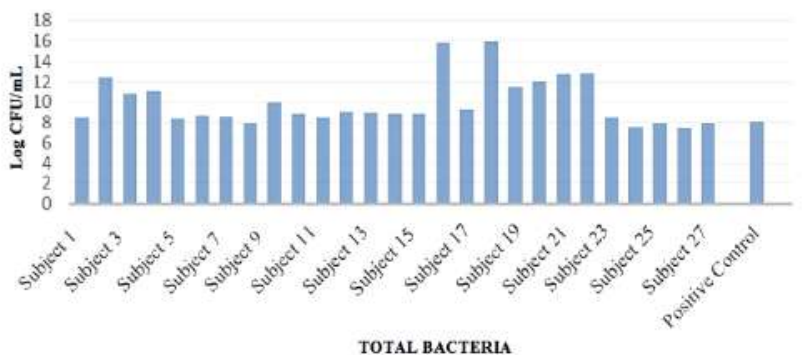

Figure 1. Graph of the total bacterial colony count in saliva.

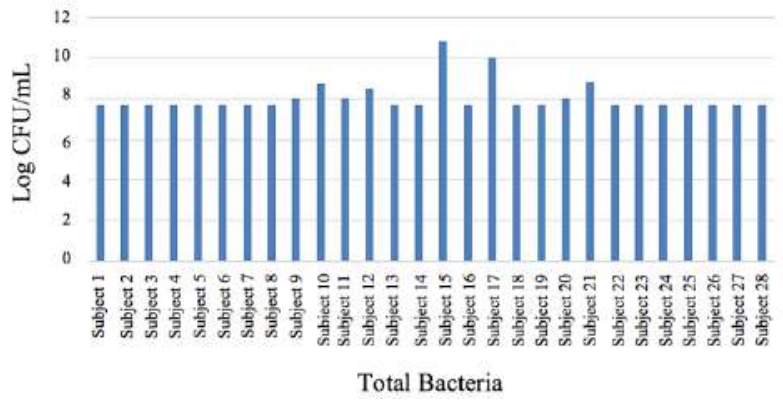

Figure 2. Graph of the of $S$. mutans number in saliva. 


\section{DISCUSSION}

The sampling of saliva was a non-invasive procedure, and it was easily performed. ${ }^{12}$ The researchers selected this age range on the basis of the study reported by Natamiharja and Margaret, where such children still had basic knowledge about the maintenance of oral and dental health. ${ }^{13}$

The number of $S$. mutans is in the high category due to the fact that the number is greater than $10^{5}$. The high number of $S$. mutans can be one of the indicators to determine a high-risk caries category. Based on the research conducted at Department of Pediatric, Faculty of Dentistry, Trisakti University, a correlation exists between the number of $S$. mutans and caries. The number of $S$. mutans in patients with active caries is greater than that of a caries-free patient. In 2018, Indonesian Basic Health Research (RISKESDAS) has reported that children aged between 5 and 9 years exhibit 54\% oral and health problems. ${ }^{2}$ High-risk caries in children can be caused by the lack of basic knowledge about the maintenance of oral and dental health. Sweet consumption by children cannot be prevented. Meanwhile, food containing sugar is one of the causes of caries. This result is supported by that reported in a study by Rosidi et al., where they revealed that there is a significant correlation between tooth caries and cariogenic food consumption. ${ }^{14,15}$

Determination of caries risk in children can be utilized as a reference for the determination of an appropriate preventive treatment plan. Primary preventive treatment for high-risk caries children is dental health education (DHE) to children and parents, which includes the explanation of the cause of caries, modification of children behavior (oral hygiene and diet), and instruction of teeth cleaning. Moreover, prevention also includes the modification of the host (tooth) by performing pit and fissure sealant and fluoride applications. Notoatmodjo et al. reported that parents play an important role in the maintenance of oral and dental health. If the family members rarely brush their teeth before bedtime, then it can affect the behavior of the children, which in turn can affect the maintenance of oral and dental health. The maintenance of oral and dental health is a reflection of the social status. Parents in the middle-to-high social economy class typically provide more comprehensive health care than the low social economy class. ${ }^{16}$

The high number of $S$. mutans in children at the Department of Pediatric, Faculty of Dentistry, Trisakti University was probably caused by the lack of knowledge on the part of the children and parents toward the maintenance of oral and dental health. The socio- economic status might have impact on caries activity. Therefore, the Department of Pediatric, Faculty of Dentistry, Trisakti University always provides DHE to each child as well as parents before treatment. In this study, some difficulties with respect to the disobedience of children and incapability of collecting saliva in children were observed. Meanwhile, some parents disagreed with the study and were afraid to allow their children to participate in it.

\section{CONCLUSION}

Based on the results, we conclude that the number of $S$. mutans in the saliva of children is in the high-risk category in children at the Department of Pediatric, Faculty of Dentistry, Trisakti University. Further study needs to be done with more samples.

\section{CONFLICT OF INTEREST}

There is no conflict of interest in this study.

\section{REFERENCES}

1. Yadav K, Prakash S. Dental caries: A review. Asian J Biomed Pharm Sci. 2016;53(4):369-377.

2. Indonesia. Badan Penelitian dan Pengembangan Kesehatan. Riset Kesehatan Dasar (RISKESDAS) 2018. Jakarta: Badan Penelitian dan Pengembangan Kesehatan. 2018. pp.81-202.

3. Rosdiana N, Nasution AI. Gambaran daya hambat minyak kelapa murni dan minyak kayu putih dalam menghambat pertumbuhan Streptococcus mutans. J Syiah Kuala Dent Soc. 2016;1(1):43-50.

4. Pradopo S. The colony number of Streptococcus mutans and Lactobacillus in saliva of dental caries and free caries children. Maj Ked Gigi (Dent J). 2008;41:53-55.

5. Chokshi A, Mahesh P, Sharada P, Chokshi K, Anupriya S, Ashwini B. A correlative study of the levels of salivary Streptococcus mutans, lactobacilli and Actinomyces with dental caries experience in subjects with mixed and permanent dentition. J Oral Maxillofac Pathol. 2016;20(1):25-8.

6. Sylvania DA, Gultom FP, Bachtiar BM. Korelasi kuantitas Streptococcus mutans pada plak lidah dan saliva dengan risiko karies tinggi - Corelation between quantity of Streptococcus mutans in tongue plaque and saliva and high risk caries. J FKG UI. 2014.

7. Acevedo A, Ray M, Socorro M, Rojas-Sánchez F. Frequency and distribution of Mutans Streptococci in dental plaque from caries-free and caries-affected Venezuelan children. Acta Odontol. 2009;22(1):1520.

8. Alhamda S. Status kebersihan gigi dan mulut dengan 
status karies gigi (kajian pada murid kelompok umur 12 tahun di Sekolah Dasar Negeri Kota Bukittinggi). Berita Kedokteran Masyarakat. 2011;27(2):108-15.

9. Rotimi VO, Salako NO, Divia M, Asfour L, Kononen E. Prevalence of periodontal bacteria in saliva of Kuwait children at different age group. J Infect Public Health. 2010;3:76-82.

10. Widyarman AS, Hartono V, Marjani LI, Irawan D, Luthfi L, Bachtiar BM. Lactobacillus reuteri containing probiotic lozenges consumption reduces Streptococcus mutans, Streptococcus sobrinus, Porphyromonas gingivalis, and Aggregatibacter actinomycetemcomitans in orthodontic patients. J Int Dent Res. 2018;11(2):628-633.

11. Yoshizawa JM. Salivary biomarkers: toward future clinical and diagnostic utilities. 2013;26:781-791. Natamiharja L, Margaret. Peran orangtua terhadap pemeliharaan kesehatan gigi dan mulut anak kelas II SD Medan. Dentika Dent J. 16:163.

12. RoSanz AMG, Nieto BAG, Nieto EG. Dental health: relationship between dental health and food consumption. Nutr Hosp. 2013;28(Supp14):64-71.

13. Forssten SD, Björklund M, Ouwehand AC. Streptococcus mutans, caries and simulation models. Nutrients. 2010;2(3):290-298.

14. RoSanz AMG, Nieto BAG, Nieto EG. Dental health: relationship between dental health and food consumption. Nutr Hosp. 2013;28(Suppl4):64-71.

15. Alphianti LT, Mei A. Jigsaw versus Conventional Method towards Children's Attitude and Knowledge of Dental and Oral Health. 2019;2(2):69-74.

16. Forssten SD, Björklund M, Ouwehand AC. Streptococcus mutans, caries and simulation models. Nutrients. 2010;2(3):290-298. 